\title{
CANTERBURY AND ROME
}

$\triangle$ DEEP sense of responsibility urged us to A write in our July issue some of the thoughts that filled our soul on the eve of the Lambeth Conference. We were of those who could see, and even profess to see a unique event in the assembly of two hundred and fifty Bishops in communion with the Sees of Canterbury and York. These Bishops, belonging to the two great English-speaking nations, could not discuss after-war problems in the spiritual sphere without wielding a power for good, which, like every other power, might be turned to evil even when used with good intent. It was part of their disarming truthfulness frankly to confess that they had no mandate even from their own Church to say the last word on any subject of spiritual reconstruction. This profession of self-diffidence did not discredit them in our eyes. Rather did it put them apart from that all too numerous group of spiritual reconstructionists whose self-confidence is their chief power for evil. We were therefore ready to listen to whatever issued from the counsels of a group of men whose selfdiffidence recalled the prophetic words, "I am not the Christ."

Our readiness to listen was not disappointed. As the result of deliberations lasting some five weeks, the assembled Bishops issued: I. An Encyclical Letter. 2. An Appeal (to all Christian people on Reunion). 3. Resolutions, eighty in number. 4. Reports of Committees.

We do not think we are exaggerating the result of these deliberations by looking upon them as one of the most important steps towards social reconstruction taken since the outbreak of the Great War. In this we are probably re-echoing the quiet suffrage of the public. Although the Report is a volume of $38 \mathrm{r}$ 


\section{Blackfriars}

a hundred and sixty pages, costing two shillings, yet the first edition of 15,000 was entirely sold out within seven days. This great sale, which is probably unprecedented, is mainly due to the question of Reunion which the Report placed in such prominence. To quote an unbiassed witness, "The Appeal to all Christian people which was issued a few days ago by the Lambeth Conference has received a most cordial welcome in very various quarters. Churchmen of all schools of thought have expressed their gratitude for this plea for the Reunion of Christendom, and some of the most eminent Free Churchmen have stated their appreciation in the most emphatic way." (Daily Telegraph. 28 August.)

The Resolutions and Committee Reports deal with Christianity and International Relations-The Church and Industrial Problems-The Development of Provinces-Missionary Problems-Position of Women -Problems of Marriage-Spiritualism, Christian Science and Theosophy-Reunion. As it is with the question of Reunion that we are concerned we will set down the words of the Encyclical Letter.

.. God has called into being a fellowship of men, $\mathrm{His}$ Church, and sent His Holy Spirit to abide therein, that by the prevailing attraction of that One Spirit, He, the One God and Father of all, may win over the whole human family to that fellowship in Himself by which alone it can attain to the fullness of life. . . . The weakness of the Church in the world of to-day is not surprising when we consider how the bands of its own fellowship are loosened and broken.

The truth of this had been slowly working into the consciousness of Christians before the War. But the War and its horrors, waged as it was between so-called Christian nations, drove home the truth with the shock of a sudden awakening. Men in all communions began to think of the Reunion of Christendom, not as a laudable ambition or a beautiful dream, but as an imperative necessity. . . . The great wind was blowing over the whole earth. 


\section{Canterbury and Rome}

Such were the conditions of the time at which our Conference met. All realized that the subject of Reunion was our most important subject. The Bishops brought with them into the Conference very various preconceptions. Different traditions, different estimates of history, different experiences in the present, different opinions on current proposals, seemed almost to preclude the hope of reaching any common mind. The subject of Reunion was entrusted to the largest Committee ever appointed in a Lambeth Conference. As their, work proceeded, the members of it felt they were being drawn by a Power greater than themselves to a general agreement. Their conclusions were accepted by the Conference under the same sense of a compelling influence. The decision of the Conference was reached with a unanimity all but complete. It is embodied in our Appeal to all Christian people."

I. "All realized that the subject of Reunion was our most important subject." This is a unique spiritual phenomenon of the twentieth century. It has been forced upon the consciousness of Christianity by the visible failure of Christians to stem religious indifference. To a Roman Catholic who asked a clever, successful, and upright doctor, "Why have you no religion, doctor? " the reply was, "I am a very busy man. I will choose my religion when the ministers of religion have agreed which is the true religion!"

Ministers of religion are slowly awakening to two facts. (a) Christianity is losing to practical indifference. (b) The chief factor in this loss is the disunion of Christians, and especially of the ministers of religion.

2. It is consoling to know that no one is more conscious of these two factors than are these same ministers of religion. Whilst it is mainly due to them that the number of Christians is as large as it is, it is also mainly due to them that the number of Christians is as small as it is, and gradually becoming relatively smaller. 


\section{Blackfriars}

3. It is still more consoling to realize that the movement towards Church Reunion is largely fostered and furthered by ministers of religion. No doubt there is a very helpful backing from the laity; and even a (dangerous?) backing here and there from the politicians. But the movement, whether amongst English Churchmen or Free Churchmen, has sprung from the ranks of those ministers of religion who have come to feel in the present crisis of religion that unity alone is strength.

4. 'The two hundred and fifty Bishops summoned from all parts of the world and assembled at Lambeth, were at one with their fellow ministers of religion in seeing the need for religious Reunion. Indeed, they put Reunion at the forefront of their deliberations. Looking upon it rightly as their " most important subject " they dealt with it more determinedly than it had ever been dealt with by them before. They appointed the largest Committee ever appointed by a Lambeth Conference. The Report on Reunion was passed " with a unanimity all but complete." The Bishop of Exeter tells us that of the two hundred and fifty Bishops only three were unable to vote for the resolution! (Church Times, 20 August.)

II

The causes of the disunion of Christendom are set down with frank humility in the "Appeal."

The causes of division lie deep in the past, and are by no means simple or wholly blameworthy. Yet none can doubt that self-will, ambition, and a lack of charity among Christians have been the principal factors in the mingled process, and that these, together with blindness to the sin of disunion, are still mainly responsible for the breaches of Christendom. We acknowledge this condition of broken fellowship to be contrary to God's will, and we desire frankly to confess our share in the guilt of thus crippling the Body of Christ and hindering the activity of His Spirit. 


\section{Canterbury and Rome}

I. Something may assuredly be wanting to this statement as a formula of faith ; but nothing is wanting to it as a formula of repentance. It may not meet all the theological doctrine of the indefectibility of the Church. But it is a humble denial of the impeccability of Churchmen.

2. Bishops like his Lordship of Zanzibar give this frank acknowledgment an expression still more frank. He writes: "The Bishops are, I take it, prepared to wash the feet of their fellow-Christians ; to humble themselves before them if by any means they may be counted worthy to serve them. . . . For myself I am thankful for the Bishops' utterance. It has lifted us to a new level. We are bidden, in effect, exorcise the spirit of sectarianism from all our communions; to lift up our eyes to the vision of the universal Church and to humble ourselves at one another's feet." (Church Times, 20 August.)

Such sentiments have not come to the heart of man from the mere mind of man. A great wind has blown them thither from the mind and heart of God. If we are not within sight of the City of Peace our faces are set eastwards toward its gates.

3. We of the Roman Catholic Church, i.e. the Ecclesia Latina and the Ecclesia Orientalis (Codex Furis Canonici. Can. I), will not allow our separated brethren to accept all the sin of disunion. Long before disunion came, our saints and prophets saw it coming. They denounced it as a crime; but they denounced still more the crimes of those even in the highest quarters which brought it into being.

Even to-day our people are taught to look upon the upheaval of the sixteenth century as an effect of their own sins. "Gradually a regrettable worldliness manifested itself in many high ecclesiastics. Their chief object, viz. to guide man to his eternal goal, claimed too seldom their attention, and worldly activities became 385 


\section{Blackfriars}

in too many cases the chief interest. Political power, material possessions . . . earthly interests of various kinds were only too often the chief aim of many of the higher clergy. Pastoral solicitude, the specifically religious and ecclesiastical aim, fell largely into the background, notwithstanding various spirited and successful attempts to rectify the existing evils. Closely connected with the above were various abuses in the lives of the clergy and the people. In the Papal Curia political interests and a worldly life were often prominent. Many bishops and abbots bore themselves as secular rulers rather than as servants of the Church. ... The scientific and ascetic training of the clergy left much to be desired, the moral standard of many being very low, and the practice of celibacy not everywhere observed." If we have quoted this passage from such a representative and widely read work as the Catholic Encyclopadia (Vol. XII, p. 700. Art., Reformation), it is not for its authoritativeness, or for our agreement with its findings. Indeed, we should not be surprised if the writer of the article has painted his picture in colours too dark for truth. But for that very reason the quotation is irrefutable as an indication of the Church's present desire to acknowledge its share in the responsibility of disunion. This makes towards hope. When two parties to a quarrel cannot outdo each other in accepting blame the end of the quarrel is in sight.

\section{III}

Some noteworthy steps towards Reunion are taken in the following weighty statements :-

Terms of Reunion must no longer be judged by the success with which they meet the claims and preserve the positions of two or more uniting Communions, but by their correspondence to the common ideal of the Church as God would have it to be. . . . So long as there is vital connexion with the Head, there is positive value in the differentiation 386 


\section{Canterbury and Rome}

of the members. But we are convinced that this ideal cannot be fulfilled if these groups are content to remain in separa'tion from one another or to be joined together only in some vague federation. Their value for the fullness of Christian life, truth and witness can only be realized if they are united in the fellowship of one visible Society whose members are bound together by the ties of a common faith, common sacraments, and a common ministry. It is towards this ideal of a united and truly Catholic Church that we must all set our minds (Encyclical Letter).

We believe that it is God's purpose to manifest this fellowship, so far as this world is concerned, in an outward, visible and united society, holding one faith, having its own recognized officers, using God-given means of grace, and inspiring all its members to the world-wide service of the Kingdom of God. That is what we mean by the Catholic Church. . . . To this end, we who send forth this Appeal would say that if the authorities of other Communions should so desire we are persuaded that, terms of union having been otherwise satisfactorily adjusted, Bishops and clergy of our Communion would willingly accept from these authorities a form of commission or recognition which would commend our ministry to their congregations (Appeal to all Christian People).

. . . Should the Church of Rome at any time desire to discuss conditions of Reunion we shall be ready to welcome such discussions (Report on Reunion, Part III).

r. Again let us frankly own that as professions of faith these statements may not have been drawn up with theological accuracy.

But even their promulgators have not wished to make them professions of faith. In a truer sense they are professions of charity. We are not so zeal-blinded as to see in them the dawn of Reunion. But they are the most authentic promise of dawn that has yet appeared in the dark night legacied to us by the sixteenth century.

2. There is a clear, definite enunciation of the necessity of the "Visible Church." This is not to $3^{87}$ 


\section{Blackfriars}

deny-indeed it may even demand-the necessity of an "Invisible Church"; since it is not outward, visible professions of faith, but the inner, hidden life of charity that saves the human soul by uniting it to the Soul of the Church.

3. The visible Church is one in faith, in sacraments, in ministry. In the Report of the Committee it is said :

It is of first importance, in order to remove Oriental misconceptions, to make it clear from our formularies that we regard Ordination as conferring grace, and not only as a mere setting apart to an ecclesiastical office.

The Church Times has some helpful words on this attitude of the Conference. In a leading article (27 August) it says : "The point upon which most stress has been laid is the patent conviction of the bishops that nothing can be done unless Nonconformists are willing to submit to episcopal ordination. They have in view not only Reunion with Protestants, but Reunion with Rome and the East, neither of which would hear of Reunion on any other basis. ... (Some Nonconformists) seem to assume that the sacramental theory of the ministry has been abandoned by the Bishops. Of course this is not so." (Then follows the passage quoted from the Report.) ... " If Rome or the East have doubts" (of our ordination) "we will submit to an ordination which will remove those doubts."

We who lived through the distressing period before and after the Apostolica Cura, saw such evidence of the human emotions engendered on both sides that we wellnigh despaired of a reconciliation. But the Bishops gathered under the shadow of St. Anselm and St. Thomas at Lambeth have made despair an act of disloyalty to Him who rules the heart.

4. This willingness to serve Reunion even by submitting to re-ordination shows a disposition of such 388 


\section{Canterbury and Rome}

readiness that we can hardly overrate the following significant words : "Should the Church of Rome at any time desire to discuss conditions of Reunion we shall be ready to welcome such discussions." It is nearly three hundred years since words such as these passed between the Mother-Church and its beloved DaughterChurch. They are too fateful, perhaps too official, to be fitly dealt with by a private theologian. They are of the nature of an invitation to proclaim an armistice with a view to a final Peace Conference. The Shepherd who guides his flock where Peter laid down his life for the sheep, will not hear this Voice of the English without feeling his Shepherd heart moved to its depths. Already the Court of St. James's has entered into official relations with the Court of St. Peter's. God grant it may be but a symbol significant and effective of another reconciliation which will mean the kiss of peace between Rome and Canterbury.

Vincent MCNabB, O.P.

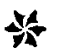

